\title{
Kerkhoff $v$ Minister of Justice and Constitutional Development 20112 SACR 109 (GNP): Intermediary Appointment Reports and a Child's Right to Privacy Versus the Right of an Accused to Access to Information
}

M Bekink*

\section{P.E.R}

Pioneer in peer-reviewed, open access online law publications.

Author

Mildred Bekink

Affiliation

University of South Africa, South Africa

Email bekinm@unisa.ac.za

Date published

3 January 2017

Editor Prof W Erlank

How to cite this article

Bekink M "Kerkhoff v Minister of Justice and Constitutional Development 20112 SACR 109 (GNP): Intermediary Appointment Reports and a Child's Right to Privacy Versus the Right of an Accused to Access to Information" PER / PELJ 2017(20) - DOI http://dx.doi.org/10.17159/17273781/2017/v20i0a1035

Copyright

\section{(†)}

DOI

http://dx.doi.org/10.17159/1727-

3781/2017/v20i0a1035

\begin{abstract}
General consensus exists that the adversarial nature of the South African criminal procedure with its often aggressive crossexamination of a witness, sometimes by an accused himself, will in most cases expose a child to undue mental stress or suffering when having to testify in court. In confirmation of this fact and with a notion to shield child witnesses from the stress or suffering when having to testify in the presence of an accused the function of an intermediary was introduced with the insertion of section $170 \mathrm{~A}$ into the Criminal Procedure Act 51 of 1977. In terms of section $170 \mathrm{~A}(1)$ a court may if it appears to such court that it would expose any witness under the biological or mental age of eighteen years to undue mental stress or suffering if he or she testified at such hearing, appoint a competent person as an intermediary in order for the witness to give evidence through that intermediary. Section $170 \mathrm{~A}(1)$ contemplates that a child complainant will be assessed prior to testifying in court in order to determine whether the services of an intermediary should be used. If the assessment reveals that the services of an intermediary are needed, then the state must arrange for an intermediary to be available at the commencement of the trail. The aforementioned procedure of section $170 \mathrm{~A}(1)$ was followed in Kerkhoff $v$ Minister of Justice and Constitutional Development 20112 SACR 109 (GP) and is the subject of this discussion.
\end{abstract}

\section{Keywords}

Section 170A, Criminal Procedure Act 51 of 1977, child witnesses, intermediaries. 


\section{Introduction}

General consensus prevails that the adversarial nature of the South African criminal procedure with its often aggressive cross-examination of a witness, sometimes by an accused himself or herself, will in most cases expose a child to undue mental stress or suffering when having to testify in court. ${ }^{1}$ In confirmation of this fact and with a view to shielding child witnesses from stress or suffering when having to testify in the presence of an accused, intermediaries were introduced into criminal procedures with the insertion of section 170A into the Criminal Procedure Act. ${ }^{2}$ Section $170 \mathrm{~A}(1)$ of the Act provides that:

Whenever criminal proceedings are pending before any court and it appears to such court that it would expose any witness under the biological or mental age of 18 years to undue mental stress or suffering if he or she testifies at such proceedings, the court may, subject to subsection (4) appoint a competent person as an intermediary in order to enable such witness to give his or her evidence through that intermediary.

With the amendment of the Criminal Procedure Act the legislature recognised the difficult circumstances under which children have to testify and purported to ameliorate the difficulties experienced by them during such proceedings through the application of section 170A. This was confirmed by the Constitutional Court in DPP v Minister of Justice, ${ }^{3}$ where the court emphasised that the subsection had been enacted for the purpose of protecting a child complainant from undergoing undue mental stress or suffering that may be caused by testifying in court, and that this purpose is consistent with the principle that the best interests of children are of paramount importance in criminal trials involving child witnesses. ${ }^{4}$

The Constitutional Court furthermore per Ngcobo $\mathrm{J}$ affirmed that:

Mildred Bekink. LLB (Unisa), LLM (Pret). Senior Lecturer at the Department of Mercantile Law, College of Law, University of South Africa. Email: bekinm@unisa.ac.za.

1 Director of Public Prosecutions v Minister of Justice and Constitutional Development 20094 SA 222 (CC) [108] (hereinafter referred to as DPP v Minster of Justice). Also see SALC Protection of the Child Witnesses; Schwikkard 1996 Acta Juridica 155; Müller 2000 CARSA 15-17; Matthias and Zaal 2011 Int'l J Child Rts 251.

2 Criminal Procedure Act 51 of 1977 (hereinafter referred to as the Criminal Procedure Act, as amended by the Criminal Law Amendment Act 135 of 1991 and the Criminal Law (Sexual Offences and Related Matters) Amendment Act 32 of 2007.)

$3 \quad$ DPP $v$ Minister of Justice para [95].

4 See s 28(2) of the Constitution of the Republic of South Africa, 1996 hereinafter referred to as the Constitution. Note also the preamble of the Criminal Law (Sexual Offences and Related Matters) Amendment Act 32 of 2007, that acknowledges that children are among the most vulnerable members of society. 


\begin{abstract}
... it must be accepted that a child complainant in a sexual offence who testifies without the assistance of an intermediary faces a high risk of exposure to undue mental stress or suffering" and "that the object of $\mathrm{s} 170 \mathrm{~A}(1)$ read together with $\mathrm{s} 170 \mathrm{~A}(3)$ is precisely to prevent this risk of exposure. It does this by making provision for a child to testify through the intermediary. ${ }^{5}$
\end{abstract}

The Constitutional Court pointed out that section 170A(1) does not require that a child first be exposed to undue mental stress or suffering before the section may be imposed. The section contemplates that a child complainant will be assessed prior to testifying in court in order to determine whether the services of an intermediary should be used. If the assessment reveals that the services of an intermediary are needed, then the state must arrange for an intermediary to be available at the commencement of the trail. ${ }^{6}$ The aforementioned procedure of section 170A(1) was followed in Kerkhoff $v$ Minister of Justice and Constitutional Development 20112 SACR 109 (GP), ${ }^{7}$ which is the subject of this discussion. Aspects incidental to the procedure followed in section $170 \mathrm{~A}(1)$, namely the confidentiality or not of the documents relating to the assessment itself, will also form part of this discussion.

\title{
2 Facts
}

The Kerkhoff case relates to a notice of motion in the North Gauteng High Court of South Africa in which the applicant (Kerkhoff) sought a variety of relief orders including that some of the respondents (the Minister of Safety and Security, the Director of Public Prosecutions, Advocate $\mathrm{J}$ Cronje and Captain Collin Morris of the Randburg SAPS) be found to be in contempt of court for failing to comply with certain previous court orders that had been granted. The applicant also sought an order directing the sixth respondent (the Teddy Bear Clinic) and the seventh respondent (Shaheda Omar, a social worker in the employ of the sixth respondent) to make the contents of the docket, such contents as were in their possession, and the documents listed in Annexure "A" attached to the notice of motion, available to the applicant. ${ }^{8}$

The applicant in the matter, a Catholic priest, faced several criminal charges in the Brits Regional Court, including charges of sexual assault, charges of

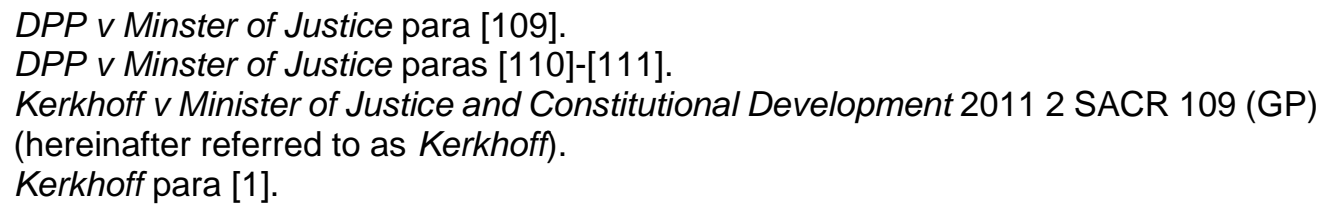


compelling or causing children to witness a sexual act, and also a charge of (common) assault. The state intended to call five complainants, all of them boys between the ages of ten and eleven, to testify against the applicant. The state also intended to use the provisions of section 170A of the Criminal Procedure Act to enable the five complainants to testify in the trial with the assistance of an intermediary. The intention of the state to apply the provisions of section $170 \mathrm{~A}$ meant that at the commencement of the trial the state had to request the court to appoint an intermediary or intermediaries to assist the complainants to give evidence. In an effort to assist the court to make its decision regarding the appointment of an intermediary, the state obtained intermediary reports from the sixth respondent's employee, one Shaheda Omar, the seventh respondent, who was a qualified social worker. The seventh respondent recommended that the five complainants should testify through an intermediary. ${ }^{9}$

The applicant, however, opposed the appointment of an intermediary to assist the complainants and wanted them to testify in open court without the protection that section $170 \mathrm{~A}$ affords to children. ${ }^{10}$ The applicant indicated that he intended to attack the seventh respondent's assessment of the five children as well as her reports and that "the evidence of the five complainants is neither competent nor admissible". ${ }^{11}$ In order to achieve this outcome, the applicant sought access to the seventh respondent's working papers, which contained the raw data from which she compiled her reports. These documents were listed in Annexure " $A$ " attached to the motion of notice. It should be noted that both the sixth and seventh respondents refused to make such data and documents available to either the prosecution or the defence as they considered them to be private and confidential. $^{12}$

The matter was subsequently brought before the North Gauteng High Court, which, apart from the matter concerning the contempt of court, was faced with the issue of whether the accused had a right to disclosure of the particular documentation, namely copies of the working papers containing the raw data from which the intermediary reports were compiled. In view of the court's decision, this discussion will focus on the courts' approach in addressing this issue in order to indicate whether an accused has a right to access to the said information.

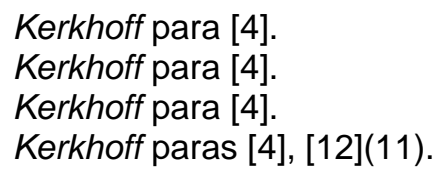




\subsection{Sequence of events}

In order to have an understanding of the orders sought by the applicant it is necessary to have a broad view of the sequence of the events of the case. They can be briefly summarised as follows:

- In February 2008 the applicant's attorney became aware of the fact that the applicant was being investigated for allegedly indecently assaulting four young boys who were members of his First Communion class. She instructed counsel and made contact with the investigating officer (the fifth respondent) in an attempt to have the case withdrawn.

- $\quad$ The aforementioned approach was unsuccessful and on 5 June 2008 the applicant was charged and appeared before the Brits District Court. The case was postponed for further investigation and for the state to obtain intermediary reports.

- $\quad$ On 12 June 2008 the applicant applied to the Brits District Court for an order that the whole police docket (ie section A, B and C) be disclosed to the applicant. This order was granted.

- On 12 August 2008 the applicant appeared before the Brits Regional Court. The case was postponed for trial on 8 and 9 October 2008. The state again sought the postponement in order to obtain intermediary reports.

- $\quad$ On 8 October 2008 the trial was once more postponed to 23 March 2009 due to the unavailability of an interpreter. At the hearing the applicant's counsel applied to the court for the applicant to have access to a test done by the social worker on the complainants, and handed in a list of the documents to which access was sought (Annexure "A"). The prosecutor at the time had no objection to the request and the court ordered that "the defence be supplied with all the issues and documentation raised in the list annexed hereto [as] Annexure 'A'". The prosecutor and the applicant's legal representative agreed that the state would supply the defence with the relevant documentation on 17 October 2008. The prosecutor, however, failed to do so.

- $\quad$ On 11 November 2008 a meeting was held between all the parties to discuss amongst other things the discovery of the documents listed 
in Annexure "A". The applicant's counsel requested assistance in obtaining these documents.

- $\quad$ After the meeting the fourth respondent, who had been appointed to conduct the trial in the Brits Regional Court, perused the docket and established that the documents listed in Annexure "A" did not form part of the police/court docket, neither were they in the state's possession, but they were in the possession of the sixth and or seventh respondents ie the social worker and her employer the Teddy Bear Clinic. The fourth respondent communicated with the investigating officer to establish what the situation regarding the documents was and was informed by him that the sixth and seventh respondents would not make the documents available as they were regarded by the two respondents as private and confidential. Nevertheless, the investigating officer did obtain pro forma documents (structural questions and anatomical drawings) and an explanatory note made by the seventh respondent with regards to the techniques used to assess the complainants.

- $\quad$ The third respondent, representing the office of the Director of Public Prosecutions, faxed these documents to the applicant's attorney on 1 December 2008. This was done under cover of a letter pointing out that the state had never been in possession of the documents listed in Annexure " $\mathrm{A}$ " and that counsel for the state had been informed that the documents were private and confidential and would not be made available to the state or the defence.

- $\quad$ The applicant subsequently referred the matter to the North Gauteng High Court in the form of a notice of motion. The applicant inter alia sought final relief in the form of an order that the second respondent (the Minister of Safety and Security) and/or the third respondent (the Director of Public Prosecutions) and/or the fourth respondent (Adv J Cronje) and/or the fifth respondent (Captain Collin Morris, Randburg SAPS) be found in contempt of the court orders of 12 June 2008 and 8 October 2009; directing them to forthwith comply with such court orders, as well as an order directing the sixth and seventh respondents to make the contents of the docket, such contents as are in their possession, as well as the documents contained in Annexure " $\mathrm{A}$ " attached to the notice of motion available to the applicant. 


\section{Issues of law}

The three main issues before the North Gauteng High Court were firstly whether the aforementioned respondents were in contempt of court, secondly whether the seventh respondent's working papers containing the raw data used by her to compile her reports formed part of the police docket, and thirdly whether the applicant had demonstrated a right to the disclosure of the documents listed in Annexure "A".

As the focus of this paper is on the latter two issues, namely whether the seventh respondent's working papers containing the raw data used by her to compile her reports formed part of the police docket and whether the applicant had demonstrated a right to the disclosure of the documents, suffice it to say that with regards to the first issue the court found that the applicant's claim for relief based on contempt of court had not been successfully proven and could therefore not succeed. ${ }^{13}$

With regards to the second and third issues, to make out a case for the substantive relief sought by the applicant, the applicant had to demonstrate that he had a right to access to the documents sought. In support of this the applicant's counsel argued that the documents listed in Annexure "A" (the working papers containing the raw data of the seventh respondent used to compile her reports) formed part of the police docket. The applicant's counsel furthermore contended that in the light of the order of the Brits District Court of 12 June 2008 that the whole docket be disclosed to the applicant, the sixth and seventh respondents were obliged to make the documents available.

In support of their arguments the applicant's counsel relied on the rules laid down in the judgement of Shabalala $v$ Attorney-General of Transvaal, ${ }^{14}$ in which the Constitutional Court sets out the legal position with regard to the disclosure of documents in a police docket, as well as section 32 of the Constitution, which provides that "everyone has the right of access to... (b) any information that is held by another person and that is required for the exercise or protection of any rights". The applicant's counsel made no reference to the provisions of the Promotion of Access to Information Act. ${ }^{15}$

Kerkhoff para [13].

Shabalala v Attorney-General of Transvaal 19961 SA 725 (CC) (hereinafter referred to as Shabalala).

15 Promotion to Access to Information Act 2 of 2000 (hereinafter referred to as PAIA). See Kerkhoff para [15]. PAIA was enacted to give effect to the constitutional right to access to information held by both private and public bodies. PAIA seeks to give effect 
The North Gauteng High Court considered the rules as laid down in Shabala, but found that the documents listed in Annexure "A" (the working papers containing the raw data of the seventh respondent used to compile her reports) did not form part of the police docket and were thus not covered by the decision in the said case. As far as section 32 of the Constitution was concerned, the court held that the applicant's counsel did not provide any authority for the proposition that the applicant was entitled to simply rely on this section in the Constitution whilst ignoring the provisions of PAIA, which was enacted to give effect to section 32 of the Constitution. The court, and rightly so, with reference to the case of Institute for Democracy in South Africa $v A N C^{16}$ found that parties must assert the right to access to information via PAIA and that section 32 is therefore not capable of serving as an independent legal basis or cause of action for the enforcement of rights to access to information. ${ }^{17}$ As the applicant had failed to make use of PAIA and no right to access to the documents had been demonstrated, the High Court dismissed the application. ${ }^{18}$

\section{$4 \quad$ Analysis and comments}

In assessing the judgement under discussion, it is submitted that the decision and conclusions in Kerkhoff are correct and should be supported. In this regard I should like to highlight four aspects of the case which are of importance and warrant further discussion.

Firstly, Southwood J highlighted that the police docket is comprised of three sections: section A (containing the witnesses' statements taken by the investigating officer, expert reports and documentary exhibits), section B (containing witnesses' reports and memoranda), and section $\mathrm{C}$ (containing the investigation diary). The court accordingly held, and appropriately so, that the documents listed in Annexure "A" namely the working papers containing the raw data of the seventh respondent used to compile her

to this right subject to justifiable limitations in a manner which balances the right to access to information with any other rights, including the rights set out in the Bill of Rights. PAIA also aims to establish voluntary and mandatory mechanisms or procedures which enable a person to obtain access to the records of private or public bodies as swiftly, inexpensively and effortlessly as is reasonably possible. In so doing PAIA aspires to change the secretive, unresponsive culture of the pre-democratic era into a culture of transparency, accountability and effective governance. See $s 9$ of PAIA.

16 Institute for Democracy in South Africa v ANC 20055 SA 39 (C) (hereinafter referred to as Institute for Democracy).

17 Kerkhoff para [17]. Also see the court's references to Currie and Klaaren PAIA Commentary para 2.12 in support of its conclusion.

18 Kerkhoff paras [18]-[19]. 
reports did not form part of the police docket and were thus not covered by the rules in Shabalala. The court fittingly concluded that the applicant had failed to demonstrate a right to access to the documents in terms of Shabalala. ${ }^{19}$

Secondly, Southwood $\mathrm{J}$ reaffirmed that the purpose of section 170A of the Criminal Procedure Act is to determine whether an intermediary should be appointed in order to prevent a child from being exposed to undue mental stress or suffering whilst having to testify. The learned judge suitably drew attention to the fact that an enquiry in terms of section 170A of the Criminal Procedure Act has a narrow focus, namely to determine whether it is in the best interests of the child that an intermediary be appointed. The enquiry is not concerned with whether the child is competent to give evidence or whether the child's evidence is admissible, credible or reliable. ${ }^{20}$ The alleged purposes of the applicant to obtain the documents, namely "to challenge the complainants' competence to give evidence, credibility and admissibility of their evidence at trial within a trial during the proceedings" or "to make representations to the Director of Public Prosecutions regarding the withdrawal of the prosecution" were misconceived. ${ }^{21}$ The procedure envisaged in section $170 \mathrm{~A}$ does not allow for a trial within a trial of the nature contemplated by the applicant's legal counsel. The issues of the child witness's competence, admissibility, credibility and reliability were separate issues which were to be decided, in the light of all the evidence, by the trial court in the course of the trial itself. ${ }^{22}$

The aforementioned approach, the court stated, ${ }^{23}$ with reference to DPP $v$ Minister of Justice, ${ }^{24}$ not only protects child complainants from unnecessary trauma, but helps to ensure that the trial court receives evidence that is more freely presented, more likely to be true, and more likely to be better understood by the court. The fairness of the trial accordingly stood to be enhanced rather than impeded by the use of section 170A of the Criminal Procedure Act. The special procedures contemplated in section $170 \mathrm{~A}$ should consequently not be seen as justifiable limitations on the right to a fair trial, but as conducive to a trial that was fair to all. ${ }^{25}$

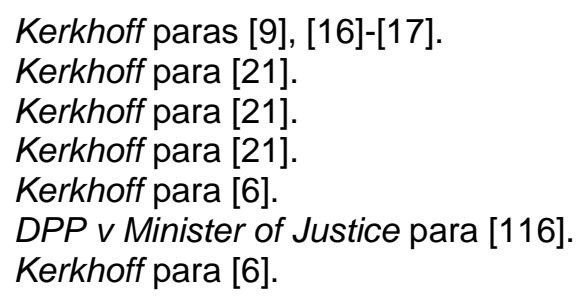


Thirdly, as was stated before, the sixth and seventh respondents claimed that the documentation referred to in Annexure "A", namely the working papers which contained the raw data used by the seventh respondent to compile her report, were private and confidential. ${ }^{26}$ This raised the question of whether the communications between a child complainant and the person tasked with compiling a report pertaining to the appointment of an intermediary are subject to professional privilege. This question was unfortunately not addressed by the North Gauteng High Court.

As a general rule professional privilege applies only to the lawyer-client relationship and is not enjoyed (at least to the same degree) by other professional relationships. ${ }^{27}$ The Criminal Procedure Act in its current form does not prescribe who will be regarded as a competent person to compile a report assisting the court in its task to determine whether an intermediary should be appointed ${ }^{28}$ and thus the possibility exists that this task may be performed by a legal advisor (such as an advocate in the office of the Family Advocate) specialising in child law. However, for a child complainant to be able to claim the professional lawyer-client privilege, the communication between the child and the legal advisor must, in terms of the requirements for the operation of the privilege, have been made for the purpose of obtaining legal advice. ${ }^{29}$ As this is clearly not the purpose of the communications between the child complainant and the legal advisor this may result in the child not being able to claim the common law professional privilege.

Furthermore, it should be noted that the task of compiling a report for the appointment of an intermediary is usually performed by a social worker or a psychologist. ${ }^{30} \mathrm{~A}$ review of the statutory law as well as the common law reveals no established professional privilege between a social worker and a child complainant and/or a psychologist and a child complainant in this capacity. This can perhaps be attributed to the fact that the use or function of an intermediary in terms of section $170 \mathrm{~A}$ of the Criminal Procedure Act is

26 Kerkhoff para [12](11).

27 Schwikkard "Evidence" para 52-69.

28 Note that the Criminal Procedure Act prescribes only who will be regarded as a competent person to be appointed as an intermediary - see s 170A4(a) of the Criminal Procedure Act; GN R137 in GG 150 of 30 July 1990, as amended by GN R360 in GG 1782 of 28 February 1997, as amended by GN R597 in GG 22435 of 2 July 2001.

29 Lane v Magistrate, Wynberg 19972 SA 869 (C); also see Zeffert and Paizes Essential Evidence 203-204 for more on the requirements for the operation of the privilege.

30 See for example Kerkhoff; $K v$ the Regional Court Magistrate 19961 SACR 434 (E) (hereinafter referred to as Regional Court Magistrate); $S$ v Mokoena; $S$ v Phaswane 20082 SACR 216 (T); S v SN 20122 SACR 317 (GNP); S v Peyani 20142 SACR 127 (GP) (hereinafter referred to as Peyani). 
still a fairly new concept ${ }^{31}$ and that the necessity of such a privilege has not been an issue until fairly recently.

Conversely, even if such a professionally-based privilege at common law may fail, some professional communications may be protected from disclosure by the constitutional right to privacy. ${ }^{32}$ Section $14(d)$ of the Constitution provides that everyone has the right not to have the privacy of their communications infringed. A communication between a social worker/psychologist and a child complainant in this capacity may well be regarded as a personal and private communication, as children, their guardians and their parents approach such a social worker/psychologist in the confidence that their communications with the social worker/psychologist will not be disclosed. Such confidentiality is essential to the full and satisfactory maintenance of the relationship between the social worker/psychologist and the child who seeks the social worker's/psychologist's assistance. ${ }^{33}$ The relationship between the child complainant and the social worker/psychologist is clearly one that should be sedulously fostered and a case can be made out that the disclosure of the communication would not be consistent with the principle that the best interests of the child are of paramount importance in criminal proceedings. ${ }^{34}$ The best interests of the child principle is both a self-standing right and a guiding principle in all matters affecting children. ${ }^{35}$ This has been confirmed by the Constitutional Court's application of the best interest principle in a variety of cases involving children's rights, including children's right to privacy. ${ }^{36}$ The post-constitutional position may therefore, in view of the constitutional recognised right to privacy and the paramountcy of the best interests of the child principle, be different from the common law position.

Where an accused seeks to compel the disclosure of a communication of a personal and private nature, the child complainant may accordingly assert that a privilege attaches to the child's relationship with the social

31 Section 170A of the Criminal Procedure Act was inserted by s 3 of the Criminal Law Amendment Act 135 of 1991 and came into operation on 30 July 1993.

32 Schwikkard "Evidence" para 52-69.

33 Kerkhoff para [12](11).

34 See s 28(2) of the Constitution. See for example Bekink and Bekink 2004 De Jure 21; Heaton 1990 THRHR 95; Ferreira 2010 THRHR 201 for more on the best interest of the child principle.

35 Minister of Welfare and Population Development v Fitzpatrick 20003 SA 422 (CC) paras [17]-[18].

36 Also see for example Johncom Media Investments Ltd v M 20094 SA 7 (CC); Teddy Bear Clinic for Abused Children v Minister of Justice and Constitutional Development 20142 SA 168 (CC), where the Constitutional Court emphasised the importance of this principle in relation to the privacy of children. 
worker/psychologist in terms of section 14 of the Constitution. However, the prima facie recognition of the privilege may be limited if the accused is able to persuade the court that the limitation of this right is justified when the accused's right to a fair trial is weighed up against the minor's rights. In order to succeed, the accused will have to prove on a balance of probabilities that unless the information is obtained, the accused's right to a fair trial will be irreparably infringed. ${ }^{37}$

It is submitted that in the light of the fact that the communication between the child witness and the social worker/psychologist pertaining to the appointment of an intermediary does not form part of the police docket and the state's case against an accused, its non-disclosure does not irreparably infringe an accused's right to a fair trial. ${ }^{38}$ The Constitutional Court in DPP $v$ Minister of Justice ${ }^{39}$ furthermore emphasised that the fairness of a trial stands to be enhanced rather than impeded by the use of the procedures set out in section 170A. The procedures should therefore not be seen as justifiable limitations to a fair trial, but instead as being conducive to a fair trial.

It should also be remembered that the purpose of the communication between the child complainant and the social worker/psychologist is for the social worker/ psychologist to evaluate the child's linguistic, cognitive and emotional development as well as to determine whether the child will suffer undue mental stress or suffering if he or she testifies at the hearing. ${ }^{40} \mathrm{~A}$ significant part of the communication between the child complainant and the social worker/psychologist may therefore not only be private and personal but totally unrelated to the case at hand. Justification for the reasonable and justifiable limitation of section 14 of the Constitution in terms of section 36 of the Constitution read together with section 28(2) of the Constitution will in my view therefore not be easily asserted. A child complainant's communication with a social worker/psychologist in this regard may hence muster constitutional protection in terms of the child's constitutional right to privacy.

37 Prinsloo v Bramley Children's Home 20055 SA 119 (T) 128B-D (hereinafter referred to as Bramley Children's Home).

38 Kerkhoff para [6].

$39 \quad D P P \vee v$ Minister of Justice para [116].

$40 \quad$ DPP $v$ Minister of Justice para [94]. 
Fourthly, the judgement is supported in terms of the approach followed by the court with regards to the determination of the applicant's right to access to information, namely that:

... s 32 of the Constitution provides the underlying basis for and informs the rights contained in PAIA, but that the section itself is subsumed by PAIA, which now regulates the right of access to information; that parties must assert the right via the Act. ${ }^{41}$

The court correctly held that the applicant had to seek access to the documents listed in Annexure "A" in accordance with the provisions of PAIA. Only if it turned out that the provisions of PAIA did not apply would the applicant be able to follow other avenues. ${ }^{42}$ As the applicant had failed to make use of the provisions of PAIA the North Gauteng Court did not undertake an assessment of the provisions of PAIA in order to determine its application to the case under discussion. This is unfortunate as it leaves an uncertainty as to whether the outcome of the case would have been different if the provisions of PAIA had been applied. It will consequently be of value to evaluate the provisions of PAIA. ${ }^{43}$

\section{PAIA}

Before April 1994 the nature of the system of government in South African resulted in the development of a secretive and unresponsive culture in public and private bodies which often led to an abuse of power and the violation of human rights. ${ }^{44}$ This position was altered through the commencement of a new constitutional dispensation ${ }^{45}$ and specifically the enactment of section 32(1) of the Constitution, which provides that:

\section{Everyone has the right to access to any information held by the state; and any information that is held by another person and that is required for the exercise or protection of any rights.}

In terms of section 32(2) of the Constitution, national legislation must be enacted to give effect to the right to access to information. PAIA is the national legislation contemplated in section 32(2) of the Constitution and was enacted to give effect to this right. ${ }^{46}$ PAIA does this by distinguishing in

\footnotetext{
41 See Kerkhoff para [17]; Institute for Democracy para [17].

42 Kerkhoff para [18].

43 It should be noted that the purpose of this discussion is not to give a detailed discussion of PAIA, but to do so with reference to the Kerkhoff case.

44 See the Preamble of PAIA. Also see Hoexter Administrative Law 95.

45 First by $\mathrm{s} 23$ of the Interim Constitution, the Constitution of the Republic of South Africa Act 200 of 1993 and later by s 32(1) of the Constitution.

46 Large parts of PAIA came into effect in March 2001. See Proc R20 in GG 22125 of 9 March 2001.
} 
section 1 between private and public bodies. On the basis of this distinction PAIA is then divided roughly into two parts, namely the provisions dealing with the right to access to information held by public bodies on the one hand, ${ }^{47}$ and on the other, provisions dealing with the right to access to information held by private bodies. ${ }^{48}$

This right was soon relied upon in a variety of contexts and a body of case law developed rapidly, in particular that of accused persons who sought access to information contained in police dockets. ${ }^{49}$ It should be noted that in terms of section 32 (1) of the Constitution, the right to access to information in state hands is unqualified, whilst the right to access to information held by other persons (ie private persons) is qualified in that the information must be required for the exercise or protection of any rights. It must be borne in mind that the right to access to information held by either a public or private body may be limited to the extent that the limitations are reasonable and justifiable in an open and democratic society based on human dignity, equality and freedom, as contemplated in section 36 of the Constitution.

PAIA starts out by defining important terms such as personal information, request for access, public body, private body, and requester. Of particular importance is the fact that PAIA takes the Constitution's concept of "information" and narrows it down, in that the Act does not apply to information but rather to the "record". This is defined in section 1 of PAIA as information that has been recorded by a private or public body regardless of the form or medium of that record. ${ }^{50}$ As the meaning of the word "record" is defined in PAIA to include any form or medium of that record, the working papers containing the raw data used by the person responsible for compiling a report as to the merits of the appointment of an intermediary or not may be regarded by the courts in terms of PAIA as part of the "record" of the communication between such a person and the child complainant.

PAIA then sets out certain general rules of application. In terms of section 5 of PAIA the provisions of the Act apply to the exclusion of any provision of other legislation that prohibits or restricts the disclosure of a record of a

\footnotetext{
47 See part 2 of PAIA.

48 See part 3 of PAIA.

49 Hoexter Administartive Law 95. Also see for example Jeeva $v$ Receiver of Revenue, Port Elizabeth 19952 SA 433 (SE) 44ff; Phato v Attorney-General Eastern Cape 1995 1 SA 799 (E) 815D.

50 Hoexter Administrative Law 97-98. See also Garden Cities Inc v City of Cape Town 20096 SA 33 (C); Claase v Information Officer, South African Airways 20075 SA 496 (SCA).
} 
public or private body. Section 7 of PAIA introduces an internal limitation of the Act in that the section determines that PAIA does not apply in particular circumstances. In terms of section 7(1) of PAIA:

This Act does not apply to records of a public or a private body if-

(a) that record is requested for the purpose of criminal or civil proceedings;

(b) so requested after commencement of such criminal or civil proceedings, as the case may be, and

(c) the production of or access to that record for the purpose referred to in paragraph (a) is provided for in any other law.

All three of the requirements of section 7(1) must be met in order to render the provisions of PAIA inapplicable. ${ }^{51}$ In PFE International the Constitutional Court highlighted ${ }^{52}$ that the purpose of section $7(1)$ is:

to prevent PAIA from having any impact on the law relating to discovery or compulsion of evidence in civil and criminal proceedings. In the event that the production of or access to the record is provided for in any other law then the exemption takes effect. The legislature has framed $s 7$ in terms intended to convey that requests for access to records, made for the purpose of litigation, and after litigation has commenced, should be regulated by the rules of court governing such access in the course of litigation.

This underscores the fact that PAIA was not intended to have any impact on the discovery procedure in civil and criminal cases, and that once litigation has commenced discovery should be regulated by the rules of court governing such access. ${ }^{53}$ The fact that PAIA does not apply in criminal matters is of importance. PAIA can therefore not be used to obtain access to information where it is required for pending civil or criminal proceedings and where access to it is provided for in another "law". The Supreme Court of Appeal with reference to Unitas Hospital $v$ Van $W y k^{54}$ reiterated this position in Director of Public Prosecutions $v$ King,${ }^{55}$ where it was found that "other law" refers to the body of law which includes the rules relating to discovery, disclosure and privilege. The court accordingly held that if access to information is required for the purpose of criminal proceedings, the right

51 See PFE International v Industrial Development Corporation of South Africa Ltd 2013 1 SA 1 (CC) para [19] (hereinafter referred to as PFE Internationa).

52 PFE International para [21].

53 See Unitas Hospital v Van Wyk 20064 SA 436 (SCA); PFE International; MEC for Roads and Public Works, Eastern Cape v Intertrade Two (Pty) Ltd 20065 SA 1 (SCA).

$54 \quad$ Unitas Hospital $v$ Van Wyk 20064 SA 436 (SCA).

55 Director of Public Prosecutions v King 20102 SACR 146 (SCA) para [39]. 
thereto had to be sought elsewhere; for example, through the rules of discovery. ${ }^{56}$

Since rule 38(1) of the Uniform Rules of Court constitutes such a "law" as contemplated in section 7(1)(c) of PAIA, a request for access to information should be made in terms of the Uniform Rules of Court and not in terms of PAIA. PAIA does not apply in such an instance. To hold otherwise, the Constitutional Court pointed out, would result in a dual system of access to information, in terms of both PAIA and the particular court rules, and this would be disruptive to court proceedings. ${ }^{57}$

It is submitted that the three conditions set out in section 7(1) of PAIA, which must be met for PAIA not to apply, will in all probability be satisfied if the Kerkhoff case (or a future case similar to that of the Kerkhoff case) is to be decided in terms of PAIA. The documents listed in Annexure "A" of the motion were requested for the purpose of a criminal proceeding; were so requested after the commencement of the proceedings; and access to the record is provided for in other law. If a determination in terms of PAIA is indeed made, an applicant such as the applicant in Kerkhoff would have to make use of other law governing the rules of court, for example a rule 38(1) application. If the respondent in such an instance refuses to make the documents available, the issue of whether the applicant would be entitled to the documents would have to be determined by the trial court. It should, however, be noted that applicants are entitled to obtain information from a third party to the litigation in terms of a rule 38(1) application only if the evidence is relevant to the dispute between the parties to the litigation. ${ }^{58}$ It is questionable, however, whether a respondent's working papers which contain the raw data used to compile a report as to the appointment of an intermediary, and which do not form part of the police docket, would be regarded as relevant to the dispute between the parties. A rule 38(1) application may accordingly also not suffice.

Although it is submitted that PAIA would not be applicable to the circumstances referred to in the case under discussion, it is perhaps also of value to have regard to the position if PAIA would apply. Two scenarios may be envisaged, as the person tasked with compiling a report pertaining to the appointment of an intermediary may either be in the employment of the state (for example, a social worker in the employment of the Department of Social

\footnotetext{
56 Director of Public Prosecutions v King 20102 SACR 146 (SCA) para [39].

57 PFE International paras [31]-[32].

58 Bramley Children's Home para [36]; Meyers v Marcus 20045 SA 315 (C).
} 
Work) or may be in the employment of a private body (for example a social worker in the employment of a NGO such as the Teddy Bear Clinic).

The procedure allowing an individual to give effect to the individual's constitutional right to access to information in terms of PAIA is set out respectively in section 11 for the records held by a public body and in section 50 for the records held by a private body. The body that receives the request must grant access to the record unless grounds for refusing the request exist. PAIA lists a number of grounds on which a request for access can or, in some cases, must be refused. ${ }^{59}$ In so doing PAIA recognises that there are reasonable and justifiable limitations on the right to access to information, even in an open and democratic society. ${ }^{60}$ The relevant grounds for refusal to grant access to the records of public bodies, namely sections 34(1), 37(1) and 40, will be discussed first, whereafter the relevant grounds for refusal to grant access to the records of private bodies, namely sections $63,65,66$ and 67 , will be discussed.

The information officer of a public body (such as a social worker in the employment of the Department of Social Works) must refuse a request for access to the records contemplated in sections 34(1), 37(1) and 40. Section 34(1) provides for the mandatory protection of the privacy of a third party, in that an information officer of a public body must refuse a request for access to a record of the body, if its disclosure would involve the unreasonable disclosure of personal information about a third party. Section 37(1) provides for the mandatory protection of certain confidential information owed to a third party, in that an information officer of a public body must refuse a request for access to a record of the body if the disclosure of the record would constitute an action for the breach of a duty of confidence owed to a third party in terms of an agreement. Section 40 provides for the mandatory protection of records privileged from production in legal proceedings, in that an information officer of a public body must refuse a request for access to a record of the body if the record is privileged from production in legal proceedings, unless the person entitled to the privilege has waived the privilege.

A public officer's working papers containing the raw data used to compile a report as to the appointment of an intermediary may fall within the aforementioned grounds for a refusal to grant access to the records of public bodies. The communication between a child complainant and a public

59 See ss 34-46 of PAIA for public bodies and ss $64-70$ for private bodies.

60 President of the Republic of South Africa v M \& G Media Ltd 20122 SA 50 (CC) para [11] (hereinafter referred to as $M \&$ G Media). 
officer such as a social worker in the employment of the Department of Social Development will as of necessity contain certain private information and may therefore be seen as confidential. The social worker in the Kerkhoff case alluded to this fact by pointing out that a policy ("agreement") exists in terms of which the relevant documents are considered to be private and confidential. ${ }^{61}$ This confidentiality is essential to maintaining a professional relationship between the person tasked with compiling a report as to the appointment of an intermediary and the child complainant seeking the person's assistance. ${ }^{62}$ As was stated above the person tasked with compiling a report as to the appointment of an intermediary for the child complainant may assert that a constitutional privilege attaches to their relationship, bringing it within the realms of the mandatory protection of records privileged from production in legal proceedings.

The head of a private body (such as the Teddy Bear Clinic) must refuse a request for access to the records of the body contemplated in sections 63 , 65,66 and 67 of PAIA. Section 63(1) provides for the mandatory protection of the privacy of a third party, in that the head of a private body must refuse a request for access to a record of the body if its disclosure would involve the unreasonable disclosure of personal information about a third party. Section 65 provides for the mandatory protection of certain confidential information owed to a third party, in that a head of a private body must refuse a request for access to a record of the body if the disclosure of the record would constitute an action for breach of a duty of confidence owed to a third party in terms of an agreement. Section 66 provides for the mandatory protection of the safety of individuals, in that the head of a private body must refuse a request for access to a record of the body if its disclosure could reasonably be expected to endanger the life or physical safety of an individual. Section 67 provides for the mandatory protection of records privileged from production in legal proceedings in that the head of a private body must refuse a request for access to a record of the body if the record is privileged from production in legal proceedings, unless the person entitled to the privilege has waived the privilege.

As the provisions applicable to private bodies are similar to those of public bodies (apart from the added protection in terms of section 66), the working papers containing the raw data used by a private person (such as a social worker in the employment of an NGO such as the Teddy Bear Clinic) assigned with the task to compile a report as to the appointment of an

61 Kerkhoff para [12](11).

62 Kerkhoff para [12](11). 
intermediary may likewise fall within the aforementioned grounds for refusal of access to the records of a private body. It is therefore contended that an application for access to such records as were the subject of the Kerkhoff case would still not succeed even if PAIA were applicable.

Lastly, cognisance should also be taken of section 80 of PAIA. Section $80(1)$ of PAIA determines that:

Despite this Act and any other law, any court hearing and application, or any appeal against a decision on that application, may examine any record of a public or private body to which this Act applies, and no such record may be withheld from the court on any grounds.

Section 80(1) affords a court hearing an application for access to information the discretionary power to examine any record of a public or private body. This affords courts what is referred to as a "judicial peek" into the specific record, and empowers them to independently review the record in order to assess the validity of an exemption claimed. ${ }^{63}$ This discretionary power must be exercised judiciously, with due regard to the constitutional right to access to information and the difficulties parties face in presenting and refuting evidence. The standard for assessing whether a court should invoke section 80(1) in a given case is whether it would be in the interests of justice to do so. ${ }^{64}$ However, a court contemplated in section 80 (1) is duty bound in terms of section 80(2) not to disclose to any person, including the parties to the proceedings concerned, other than the public or private body referred to in subsection (1), any record of a public or private body, which on a request for access may or must be refused in terms of PAIA. A court responsible for assessing an application for access to the information such as was sought in Kerkhoff will therefore be able to independently review the working papers which contain the raw data used by the person tasked to compile a report as to the appointment of an intermediary, to assess the validity of exemptions claimed, whilst ensuring that the information contained in the record remains confidential. Only if an exemption claimed does not apply may the information be disclosed and will the applicant be entitled to view the contents thereof. This ensures that applicants are afforded access to information when an exemption does not apply while affording child complainants protection against the frivolous disclosure of the contents of their communications. ${ }^{65}$

\footnotetext{
$63 \quad M \&$ G Media para [41].

$64 \quad M \&$ G Media para [45].

65 Requests that are "manifestly frivolous or vexatious" may be refused in terms of $\mathrm{s} 45$ of PAIA.
} 


\section{Subpoena duces tecum}

The court in the Kerkhoff case albeit obiter made a reference to the possibility of an alternative method to obtain the necessary information from the seventh respondent, namely that of a subpoena duces tecum. ${ }^{66}$

In terms of section 179(1)(a) of the Criminal Procedure Act, a prosecutor or an accused may compel the attendance of any person to give evidence or to produce any book, paper or document in criminal proceedings. In order to obtain the book, paper or document a subpoena is served on the person in whose possession the relevant item is. This subpoena, referred to as a subpoena duces tecum, is served in the same manner as an ordinary subpoena. The title of the book, paper or document required must be stated in the subpoena. This procedure is available to the prosecutor and the accused. A subpoena duces tecum may be issued by an accused on a state witness. ${ }^{67}$

Section 179(1)(a) provides that a person may be compelled to produce the relevant item in criminal proceedings. Both rule 54(5) of the high court and rule 64(1) of the magistrate's court state that such a subpoena may be issued with regards to "any criminal case". Watney68 submits, which submission is supported, that the wording of section 179(1) (a) could therefore be interpreted to provide for the attendance of a person in circumstances wider than just the trial itself. He points out that this is supported by the fact that a person attending court in terms of the subpoena duces tecum is not necessarily regarded as a witness unless he or she is required to testify to identify the document. ${ }^{69}$

A person so subpoenaed is obliged to attend court with the document. Prior to being called as a witness such a person is entitled to keep the document under his or her control and may refuse to allow other parties to inspect it. In the event that such a person claims privilege of the document, the court

\footnotetext{
$66 \quad$ Kerkhoff para [18].

67 Cave $v$ Johannes 19491 SA $72(\mathrm{~T})$; Du Toit et al Commentary on the Criminal Procedure Act 23-2.

68 Watney 2012 TSAR 329.

69 Watney 2012TSAR 329. See also Picked Properties (Pty) Ltd v Northcliff Townships (Pty) Ltd 19723 SA 770 (W); Trust Sentrum (Kaapstad) (Edms) Bpk v Zevenberg 19891 SA 145 (C).
} 
will first have to decide on the validity of the claim before the person may be compelled to hand over the document. ${ }^{70}$

It is submitted that the procedure of a subpoena duces tecum would be an appropriate alternative for an accused to obtain documents or information required for his or her defence where the documents or information do not form part of the police docket and are not in the possession of the state. The court in the Kerkhoff case stated that the accused could have issued a subpoena duces tecum to the seventh respondent to obtain the document. If the seventh respondent claimed privilege and refused to make the documents available, the court would have had to consider the reasons for the refusal and make an order as to whether or not the seventh respondent was obliged to hand over the documents. ${ }^{71}$

However, even if a subpoena duces tecum is the correct approach for an accused to obtain the said documents, caution should be followed by the courts not to grant such an order readily but with due regard to the best interests of the child. As stated by Harms DP in Director of Public Prosecutions $v$ King, ${ }^{72}$ "Fairness is not a one-way street conferring an unlimited right on an accused to demand the most favourable possible treatment but also requires fairness to the public as represented by the state".

This is particularly true for children.

\section{Conclusion}

The introduction of the function of an intermediary in 1993 through the insertion of section 170A into the Criminal Procedure Act has proved to be a very welcome improvement to the plight of child complainants having to testify in criminal court cases. ${ }^{73}$ Section $170 \mathrm{~A}(1)$ not only aims to prevent a child from undergoing undue mental stress or suffering while giving testimony, but is also designed to ensure the paramountcy of the best interests of the child complainant in criminal proceedings. ${ }^{74}$

$70 \quad$ Bladen $v$ Weston 19674 SA 429 (C); Trust Sentrum (Kaapstad) (Edms) Bpk v Zevenberg 19891 SA 145 (C). Also see Kruger et al Hiemstra's Criminal Procedure 23-2.

71 Kerkhoff para[18].

72 Director of Public Prosecutions v King 20102 SACR 146 (SCA) para [5].

73 See for example Regional Court Magistrate; Peyani.

74 DPP v Minister of Justice paras [94]-[95]. 
As is often the case with new legislative developments, certain secondary issues arise due to the practical application of the legislative provisions. Such an issue secondary to the primary purpose of section $170 \mathrm{~A}$ arose as a result of the dispute in the Kerkhoff case, namely whether the working papers containing the raw data used by the person responsible for compiling a report as to the appointment of an intermediary in terms of section $170 \mathrm{~A}$ should be seen as private and confidential, or whether an accused has a right to access to the said information. This secondary issue was unfortunately not addressed by the North Gauteng High Court in the Kerkhoff case other than to conclude and correctly so that an applicant has to assert a right to the said information in terms of PAIA.

However, given the provisions of PAIA and the thoughts of the authorities mentioned above, it is concluded that PAIA will not come to the assistance of future applicants seeking to obtain access to the kind of information that was sought in the Kerkhoff case. In this regard a recourse to "other law", as contemplated in PAIA, such as a subpoena duces tecum, may prove to be the correct procedure. It is nonetheless imperative for the efficacy of section $170 \mathrm{~A}$ that the primary purpose or focus of the section, namely to determine whether or not it is in the best interest of a child complainant that an intermediary be appointed, should not be overlooked. Courts adjudicating over matters such as were the subject of the Kerkhoff case should be wary not to be side-tracked by secondary issues that could hamper the practical application of the primary purpose of section 170A.

\section{Bibliography}

\section{Literature}

Bekink and Bekink 2004 De Jure

Bekink B and Bekink M "Defining the Standard of the Best Interest of the Child: Modern South African Perspective" 2004 De Jure 21-40

Currie and Klaaren PAIA Commentary

Currie I and Klaaren $\mathrm{J}$ The Promotion of Access to Information Act Commentary (Siber Ink Cape Town 2002)

Du Toit et al Commentary on the Criminal Procedure Act

Du Toit et al Commentary on the Criminal Procedure Act (Juta Cape Town 2011) 
Ferreira 2010 THRHR

Ferreira $S$ "The Best Interests of the Child: From Complete Indeterminacy to Guidance by the Children's Act" 2010 THRHR 201-213

Heaton 1990 THRHR

Heaton J "Some General Remarks on the Concept 'Best Interest of the Child"' 1990 THRHR 95-99

Hoexter Administrative Law

Hoexter C Administrative Law in South Africa (Juta Cape Town 2012)

Kruger et al Hiemstra's Criminal Procedure

Kruger M et al Hiemstra's Criminal Procedure (LexisNexis Durban 2008)

Matthias and Zaal 2011 Int'l J Child Rts

Matthias CR and Zaal FN "Intermediaries for Child Witnesses: Old Problems, New Solutions and Judicial Differences in South Africa" 2011 Int'I J Child Rts 251-269

Müller 2000 CARSA

Müller K "The Effect of the Accusatorial System on the Child Witness" 2000 CARSA 13-23

Schwikkard 1996 Acta Juridica

Schwikkard PJ "The Abused Child: A Few Rules of Evidence Considered" 1996 Acta Juridica 148-162

Schwikkard "Evidence"

Schwikkard PJ "Evidence" in Woolman S and Bishop M Constitutional Law of South Africa (Juta Cape Town 2008) ch 52

SALC Protection of the Child Witnesses

South African Law Commission The Protection of the Child Witnesses Project 71 (The Commission Pretoria 1991)

Watney 2012TSAR

Watney M "The Prosecution's Duty to Disclose: More Reason to Litigate?" 2012 TSAR 320-330

Zeffert and Paizes Essential Evidence

Zeffert DT and Paizes A Essential Evidence (LexisNexis Durban 2010) 


\section{Case law}

Bladen v Weston 19674 SA 429 (C)

Cave v Johannes 19491 SA $72(\mathrm{~T})$

Claase v Information Officer, South African Airways 20075 SA 496 (SCA)

Director of Public Prosecutions v King 20102 SACR 146 (SCA)

Director of Public Prosecutions $v$ Minister of Justice and Constitutional Development 20094 SA 222 (CC)

Garden Cities Inc v City of Cape Town 20096 SA 33 (C)

Institute for Democracy in South Africa v ANC 20055 SA 39 (C)

Jeeva v Receiver of Revenue, Port Elizabeth 19952 SA 433 (SE)

Johncom Media Investments Ltd v M 20094 SA 7 (CC)

$K v$ the Regional Court Magistrate 19961 SACR 434 (E)

Kerkhoff v Minister of Justice and Constitutional Development 20112 SACR 109 (GP)

Lane v Magistrate, Wynberg 19972 SA 869 (C)

MEC for Roads and Public Works, Eastern Cape $v$ Intertrade Two (Pty) Ltd 20065 SA 1 (SCA)

Meyers v Marcus 20045 SA 315 (C)

Minister of Welfare and Population Development v Fitzpatrick 20003 SA 422 (CC)

PFE International v Industrial Development Corporation of South Africa Ltd 20131 SA 1 (CC)

Phato v Attorney-General Eastern Cape 19951 SA 799 (E)

Picked Properties (Pty) Ltd v Northcliff Townships (Pty) Ltd 19723 SA 770 (W)

President of the Republic of South Africa v M \& G Media Ltd 20122 SA 50 (CC) 
Prinsloo v Bramley Children's Home 20055 SA 119 (T)

S v Mokoena; S v Phaswane 20082 SACR 216 (T)

S v Peyani 20142 SACR 127 (GP)

S v SN 20122 SACR 317 (GNP)

Shabalala v Attorney-General of Transvaal 19961 SA 725 (CC)

Teddy Bear Clinic for Abused Children $v$ Minister of Justice and Constitutional Development 20142 SA 168 (CC)

Trust Sentrum (Kaapstad) (Edms) Bpk v Zevenberg 19891 SA 145 (C)

Unitas Hospital v Van Wyk 20064 SA 436 (SCA)

\section{Legislation}

Constitution of the Republic of South Africa Act 200 of 1993

Constitution of the Republic of South Africa, 1996

Criminal Procedure Act 51 of 1977

Criminal Law Amendment Act 135 of 1991

Criminal Law (Sexual Offences and Related Matters) Amendment Act 32 of 2007

Promotion to Access to Information Act 2 of 2000

Government publications

GN R137 in GG 150 of 30 July 1990

GN R360 in GG 1782 of 28 February 1997

GN R597 in GG 22435 of 2 July 2001

Proc R20 in GG 22125 of 9 March 2001

\section{List of Abbreviations}

CARSA

Int'I J Child Rts
Child Abuse Research in South Africa

International Journal of Children's Rights 
PAIA

SALC

THRHR

TSAR
Promotion to Access to Information Act 2 of 2000

South African Law Commission

Tydskrif vir die Hedendaagse RomeinsHollandse Reg

Tydskrif vir die Suid-Afrikaanse Reg 